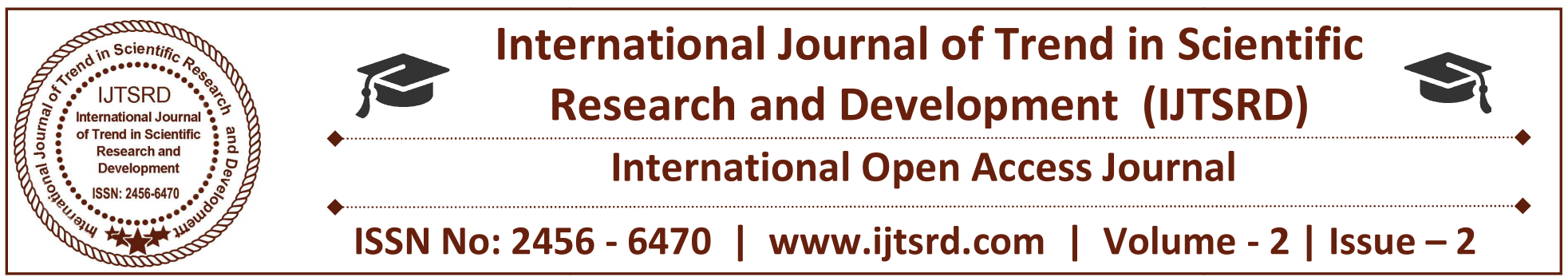

\title{
Bayesian Analysis as a Method to determine the Limitations and Advances of e-Justice
}

\author{
María Esther Hernández-Ríos, Joselito Fernández Tapia, Guillermo Alfonso De la Torre-Gea
}

\author{
Division of Postgraduate Studies, Sierra Sur University \\ Av. Guillermo Rojas Mijangos SN, Colonia Universitaria, \\ Miahuatlán de Porfirio Díaz, Oaxaca, México
}

\section{ABSTRACT}

In the process of modernization of the Public Administration, which reaches the justice systems of the region, in order to solve a de-legitimized system, with bureaucratic procedures, where there is discretion, violation of the rights of the accused and victims, and non-transparency, non-access to files by stakeholders and deprivation of liberty without sentences. Faced with this problem, Information and Communication Technologies are an instrument that has the potential to comply with the principles of publicity and transparency, streamline procedures, allow access to information and ensure prompt and expeditious justice, respecting the rights of Involved, as intended by the new Mexican criminal accusatory system. This paper aims to know the implementation of Information and Communication Technologies in the administration of justice in the State of Oaxaca, to determine their progress and limitations. The study is mixed, with the application of semi-structured interviews to judges and litigation lawyers, to know their knowledge of ICT and the use they give to their processes of formalities; As well as the documentary analysis that allows to know the legal advance and of the web pages on implantation of the TIC in the new adversarial accusatory system. In order to know the progress of the implementation of the new adversarial system, the databases on these advances will be analyzed and will determine if the use of ICT is being used in the processes that the law contemplates.
Keywords: e-Justice, adversarial system, administration of justice, Information and Communication Technologies.

\section{Introduction}

The use of information and communication technologies (ICT) in government are the result of state reform and the modernization of public administration. In this process of reform and modernization, it implies changes in the relationship of the State with the different economic actors, individuals and social groups, considered consumers or citizens (Fleury, 2000) and is carried out from a managerial approach, under the different aspects Of new public management (NGP), starting in the late 1980 s, seeking an administration that meets the needs of citizens, is accessible and encourages active participation (OECD, 1987, cited in Criado et al., 2002). Since 1997, they are also being promoted by the World Bank, in order to achieve a more efficient and transparent State (Ramírez, 2009). Electronic government is part of these reforms and modernization.

In relation to electronic government, Criado, et al. (2002) consider that information and communication technologies are "tools with (enormous) potential to configure organizational structures and public management models that offer a unique, agile, efficient, quality and transparent response of citizens" and Which must be given under the concept of New Public Management and Governance, through 
"provision of services (e-Administration), through the promotion of consultation and extension of democratic processes (e-Democracy), to processes Of public policy development (e- Governance) (Criado et al, 2002). These concepts apply equally to e-Justice: e-Administration, for the management of administrative procedures in the judiciary; EDemocracy to democratize justice to all by guaranteeing access to it as well as information and transparency; And e-Governance to achieve the expediency of the files and the participation of those involved according to the new adversarial system.

Currently, e-Justice is driven by a process of open government and governance. E-justice is seen as helping to achieve modernization and effectiveness of the State, decentralization, internal and external control, providing transparency to the public sector and reducing costs in the sector (Naser and Concha, 2011). That is, it responds to the process of modernization of public administration.

These policies include those of electronic justice, which, within the framework of the new adversarial and oral adversarial system, seek to solve the problem of the crisis of the judicial system: no-legitimating, inefficiency, bureaucracy, violation of rights Human rights of victims and defendants, lengthy judicial processes, corruption, discretion and nontransparency, and unresolved trials; Which demanded an urgent modernization. Within the framework of these changes, the legislation on access to information and transparency, such as the CNPP, incorporates ICT to justice, with a view to achieving a prompt and expeditious, transparent and respectful human rights Victims and defendants, at the same time open to society.

In Mexico, development at the criminal level is new and there are no studies yet. In Oaxaca, either. Therefore, it is important to explore the legislative, management and implementation progress, which is the objective of this project. These components and phases are those that seek to know through the study of e-justice in the State of Oaxaca, to see its progress and its limits.

For this study, a mixed method was used, with the application of semi structured interviews to judges and trial lawyers, to know their knowledge of ICT and the use they give in their procedures; As well as the documentary analysis that allows to know the legal advance and of the web pages on implantation of the
TIC in the new adversarial accusatory system. In order to know the progress of the implementation of the new adversarial system, the databases on these advances were analyzed and if the use of ICT is being used in the processes that the law contemplates.

\section{Theory}

For this research work, the numerical model of Bayesian networks was used as a representation of knowledge, which was applied in the field of Artificial Intelligence for approximate reasoning (Pearl, 1988, Mediero, 2007; Gámez, 2011). It is an important method for estimating probabilities. Sucar (2017, p.1) points out that:

Bayesian networks model a phenomenon through a set of variables and the dependency relations between them. Given this model, the Bayesian inference can be made; That is, to estimate the posterior probability of the unknown variables, based on the known variables. These models can have diverse applications, for classification, prediction, diagnosis, etc. In addition, they can give interesting information as to how domain variables are related, which can sometimes be interpreted as cause-effect relationships.

It can also be said that they are a graphical representation of dependencies for probabilistic reasoning, in which the nodes represent random variables and the arcs represent direct dependence relationship between variables. In a Bayesian network, each node represents the concepts or variables and the relationships or functions are represented by the arcs or links (Sucar, 2007). In the model, functional relations describe causal inferences expressed as conditional probabilities, in which variables are defined in a discrete or qualitative domain (De la Torre-Gea et al, 2011). This can be seen in the following equation (1):

$\mathrm{P}(\mathrm{x} 1, \ldots, \mathrm{xn})=\mathrm{P}(\mathrm{xi} \mid$ parents $(\mathrm{xi}))$

A Bayesian network could be used to identify previously undetermined relationships between the variables, being able to apply to incomplete database through description and weighting of the numerical relations, because the solution algorithm of the Bayesian network allows to calculate the probability distribution expected from The output variables (Hruscka et al., 2007, Reyes et al., 2010). "The result of this calculation depends on the probability distribution of the input variables. Overall, a Bayesian 
network can be perceived as a joint distribution of probabilities of a collection of discrete random variables "(Garrote et al., 2007), as observed in the following equation (2):

$$
P(c j \mid x i)=P(x i \mid c j) P(c j) / P(x i \mid c k) P(c k)
$$

The goal of Bayesian Networks is to achieve a better description of the observed data. The "search and result" method is based on the use of the K2 algorithm, which is considered the most representative method of automatic learning. "The idea is to maximize the probability of the structure of the data in the search space of the graph to cyclic directed respecting this order of enumeration" (Guoliang, 2009). Therefore, it is a reliable method for analyzing data and making inferences from the use of Bayesian networks. For this reason, it is important to apply them to the databases of criminal offenses to know the probabilities and trends that follow the trials when developing, and from the already realized trends. This would allow us to analyze the effectiveness of the justice system so that crimes do not go unpunished, while from knowing the trends, to know the causes of what happens in the development of trials.

\section{Materials and methods}

For the present work, we used a desktop computer Laptop Hp, with 12 GB Ram AMD A9 15 Inches and Windows 10 . Using the database of federative entities according to criminal cases concluded by the courts in criminal matters of the first instance During the year 2013, which was obtained from the INEGI portal at the national level, which was organized into a matrix of variables for the State of Oaxaca. These data were discretized using the ELVIRA system, to be used in the development of the theory of Bayesian Networks to make a description of the relationship of the variables that were taken into account for the elaboration of this work, shown in Table 1.

\begin{tabular}{|c|c|c|c|}
\hline Concept & Code & Variable & Value \\
\hline \multirow{3}{*}{$\begin{array}{l}\text { Classification of offenses } \\
\text { registered in criminal cases } \\
\text { concluded, according to the } \\
\text { type of qualification, type of } \\
\text { competition and classification } \\
\text { in order to result. }\end{array}$} & \multirow{3}{*}{$\begin{array}{l}\text { CCC_DE } \\
\text { L Inte } \\
\text { of T } \\
\end{array}$} & $\begin{array}{l}\text { Crime rating } \\
\text { national Journal }\end{array}$ & $\begin{array}{l}\text { Severe, not severe, } \\
\text { unspecified. }\end{array}$ \\
\hline & & Competition cientific & $\begin{array}{l}\text { Ideal, real, no contest, } \\
\text { unspecified }\end{array}$ \\
\hline & & $\begin{array}{l}\text { Classification and } \\
\text { of crime in order } \\
\text { of result poment }\end{array}$ & $\begin{array}{l}\text { Instantaneous, permanent, } \\
\text { continued, unspecified }\end{array}$ \\
\hline \multirow{3}{*}{$\begin{array}{l}\text { Classification of crimes } \\
\text { registered in criminal cases } \\
\text { concluded, according to the } \\
\text { type of characteristics of the } \\
\text { commission form, form of } \\
\text { action, modality, elements for } \\
\text { the commission. }\end{array}$} & \multirow[t]{3}{*}{$\begin{array}{l}\text { TIPO_EJ } \\
\mathrm{E} \\
6\end{array}$} & $\begin{array}{l}\text { Form of } \\
\text { commission } \\
\text { Form of action }\end{array}$ & $\begin{array}{l}\text { Malicious, culpable and } \\
\text { unspecified } \\
\text { With violence, without } \\
\text { violence, not specified. }\end{array}$ \\
\hline & & Modality & $\begin{array}{lr}\text { Simple, } & \text { attenuated, } \\
\text { aggravated, qualified and } \\
\text { unspecified }\end{array}$ \\
\hline & & $\begin{array}{l}\text { Elements for the } \\
\text { commission }\end{array}$ & $\begin{array}{l}\text { With weapon, with weapon, } \\
\text { with another weapon, } \\
\text { unspecified }\end{array}$ \\
\hline \multirow{3}{*}{$\begin{array}{l}\text { Classification of criminal cases } \\
\text { concluded, according to the } \\
\text { type of prosecution system or } \\
\text { oral accusatory system. }\end{array}$} & \multirow{3}{*}{$\begin{array}{l}\text { TIP_CA } \\
\text { UC }\end{array}$} & Causes completed & (Traditional System) \\
\hline & & $\begin{array}{l}\text { Criminal Causes concluded by } \\
\text { the Court of Control or } \\
\text { Guarantees }\end{array}$ & (Oral Acoustical System) \\
\hline & & $\begin{array}{l}\text { Criminal Causes concluded by } \\
\text { the Court or Oral Trial Court }\end{array}$ & (Oral Acoustical System) \\
\hline $\begin{array}{l}\text { A number of completed and } \\
\text { attempted offenses registered } \\
\text { in criminal cases concluded by } \\
\text { the courts in criminal matters } \\
\text { of the first instance during the } \\
\text { year } 2013 \text {. }\end{array}$ & $\begin{array}{l}\text { TT_DEL } \\
\text { IT }\end{array}$ & ... 21523, NULL & \\
\hline
\end{tabular}




\section{Results and Discussion}

From the National Census of State Justice Provision 2014 it can be observed that there are 184, 086 open processes; 170, 114 completed processes; 133, 624 pending cases all in criminal matters of the first instance residing in the Inquisitorial System or of Traditional Judgments. Also, it can be seen that 31, 552 are open processes; That 20,691 are completed processes; And 16, 228 are pending cases all in criminal matters of the first instance residing in the Oral Accusatory System. As can be seen in Figure 1.

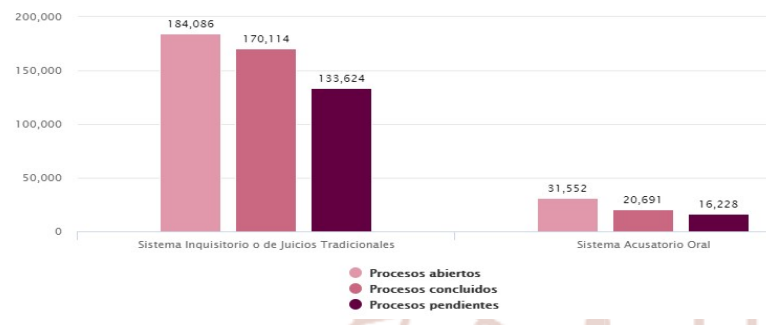

Fig. 1 Criminal matters filed in the state courts in criminal matters of the first instance by type of system according to the stage (National Census of State Justice Provision 2014).

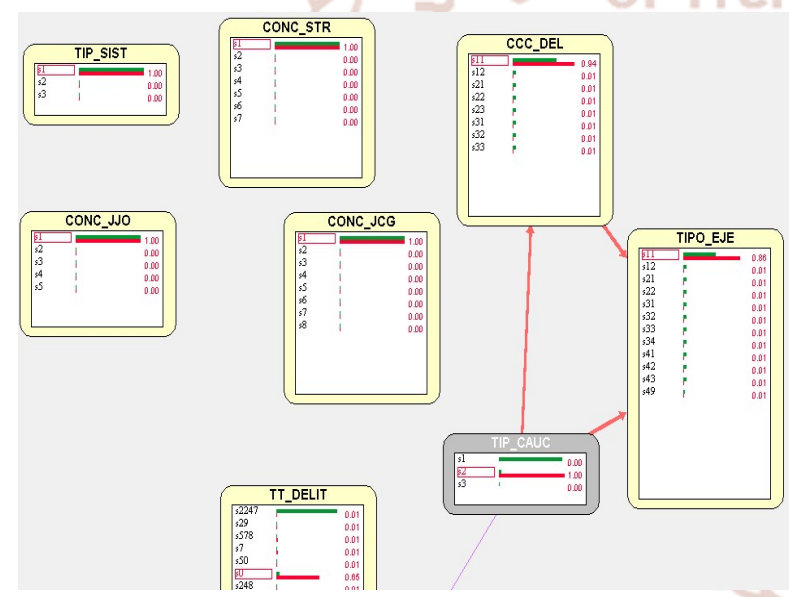

Fig 2: Bayesian classification model on the administration of justice in the State of Oaxaca. (Adversarial Accusatory System).

In Figure 2, the direct relationship between the variable TIP_CAUC, which is the classification of the criminal cases concluded, is observed through the Bayesian network on the administration of justice in the State of Oaxaca (Traditional System and the Adversarial Accusatory System) According to the type of traditional prosecution system or oral accusatory system; The variable CCC_DEL which is classification of the crimes according to the type of qualification that can be: grave, not grave and unspecified; The ideal contest type, really, there i $\mathrm{s}$ no contest and not specified.

According to the result that may be instantaneous, permanent, continuous and unspecified; Lastly the variable TYPE EJE which is the classification of the crimes registered in the criminal cases concluded, according to type of characteristics of form of commission that can be intentional, culpable; Form of action that can be with violence, without violence; According to the type of modality that is simple, attenuated, aggravated, qualified; And the elements for the commission with firearm, with weapon and another element.

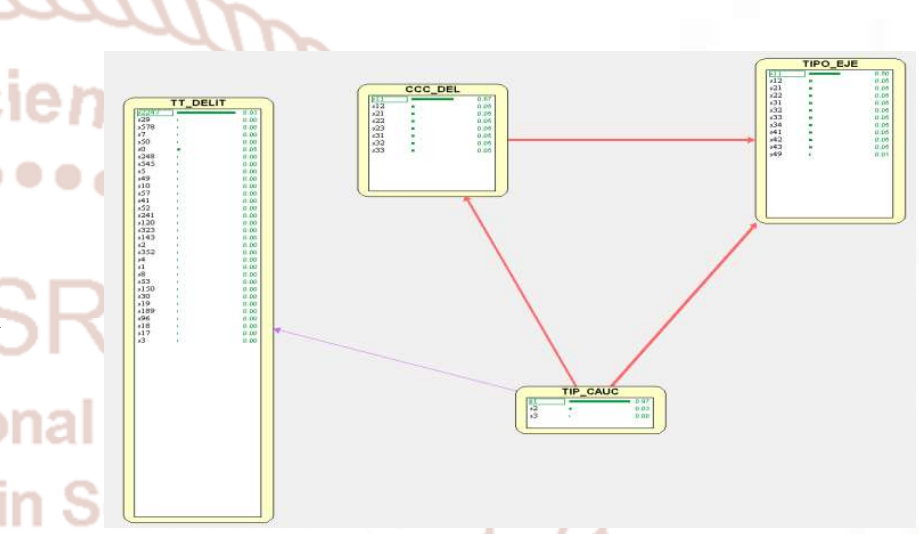

Fig 3: Clayesian classification model on the administration of justice in the State of Oaxaca. (Adversarial Accusatory System).

Figure 3 shows that according to the TT_DELIT variable, a positive prior, $97 \%$ represents the number of 2247 consumed and attempted crimes registered in criminal cases concluded by the traditional system; While 578 criminal cases representing 3\% were concluded by the new adversarial system in the Court of Control or Guarantees.

The TIP_CAUC variable of $97 \%$ on the criminal cases concluded, followed the traditional system of prosecution and only $3 \%$ of the criminal cases were concluded by the court of control or guarantees (Oral Acoustic System); As shown in Figure 2.

The variable CCC_DEL is closely related to the previous variable. $\overline{\text { It }}$ can be said that the criminal cases concluded by the traditional system $67 \%$ were for crimes that are classified as serious, And 5\% is classified as non-serious. Observe figure 2. 
According to the variable TIPO_EJE 50\% of the crimes, the form of commission was in an intentional and serious way that they were prosecuted by the traditional system; The rest of the crimes are included in $5 \%$ for the form of commission on wrongdoing, for the form of action with violence; With respect to the simple modality, the type of weapon with which they committed the crime was with firearm. As shown in Figure 2.

\section{Conclusion}

Derived from the analysis with Bayesian networks on the administration of justice in the State of Oaxaca, it is possible to affirm that, although the adversarial accusatory system was implemented since 2008, five years later, $97 \%$ of the criminal cases concluded For consummate and attempted crimes were tried by the traditional system and only 578 criminal cases concluded by the Court of Control or Guarantees have been achieved. These results can occur for two reasons: first, that since the implementation of adversarial system in the State of Oaxaca in 2008 is respecting the presumption of innocence of the accused and therefore many cases do not end in process; That is, they are considered innocent until proven guilty, and if at the time of arrest, due process is not respected, since the hearings of control and guarantee are public and transparent, the accused must remain in freedom. The Public Ministry has the obligation to integrate the investigation folder with sufficient elements to be able to request at the control hearing the order of attachment to the accuser's process; In case of defects or violation of the rights of the accused at the time of arrest, the judge of control or guarantee dictates the immediate release of the accused. The second cause would be that most of the non-serious crimes in the adversarial system are given the option of the accused and the victim to resolve the trial through alternative justice, which consists in the reparation of the damage that the accused performs to the victim. It can also be seen that the classification of offenses according to the type of qualification $67 \%$ was for serious crimes, that is to say, Are serious crimes those whose sentence is more than five years in prison and were sentenced by the traditional system.

\section{References}

1. De la torre-Gea Guillermo, Genaro M SotoZarazúa, Ramón G Guevara-González, Enrique Rico-García. (2011). Bayesian networks for defining relationships among climate factors, International Jurnal of Physic Sciences; 6 (18), 4412 - 4418.

2. Fleury, S. Reforma del Estado, Banco Interamericano de Desarrollo. En Instituto Interamericano para el Desarrollo Social (INDES), 1- 42 (2000).

3. Correa, M., Bielza, C., Paimes-Teixeira, J., Alique, J. R.: Comparison of Bayesian networks and artificial neural networks for quality detection in a machining process. Expert Syst Appl, 36(3), 7270 (2009).

4. Criado, I. y Ramilo, M. 'e-Administración: ¿un Reto o una Nueva Moda para las Administraciones del Siglo XXI? Algunos Problemas y Perspectivas de Futuro en torno a Internet y las Tecnologías de la Información y la Comunicación en las Administraciones Públicas'. Revista Vasca de Administración Pública, 61 (1), 11-43 (2001).

5. Criado, I. y Ramilo, M. Hacia una visión integrada del Gobierno Electrónico, Ekonomíaz No. 54, 3er Cuatrimestre, 206-225 (2003).

6. Criado, I., Ramilo, M. y Salvador, M. La necesidad de teoría (s) sobre Gobierno Electrónico. Una propuesta integradora. En XVI Concurso de Ensayos y Monografías del CLAD sobre Reforma del Estado y Modernización de la Administración Pública "Gobierno Electrónico", págs. 1-52 (2002), http://siare.clad.org/fulltext/0043103.pdf, acceso por última vez el 20017/01/22.

7. Garrote L, Molina M, Mediero L (2007). Probabilistic Forecasts Using Bayesian Networks Calibrated with Deterministic Rainfall-Runoff Models. In Vasiliev et al. (Eds.), Extreme Hydrological Events: New Concepts for Security, Springer, pp. 173-183.

8. Hruschka E, Hruschka E, Ebecken NFF (2007). Bayesian networks for imputation in Classification Problems. J. Intell. Inform. Syst., 29: 231-252.

9. Ramírez, M. Las reformas del Estado y la administración pública en América Latina y los intentos de aplicación del New Public Management. Estudios Políticos, 34, 115-141 (2009).

10. Reyes P (2010). Bayesian networks for setting genetic algorithm parameters used in problems of geometric constraint satisfaction. Intell. Artificial., 45: 5-8. 
11. Oszlak, O. Gobierno abierto: hacia un nuevo paradigma de gestión pública. En Colección de documentos de trabajo sobre e-Gobierno 5, Red de Gobierno Electrónico de América Latina y el Caribe - Red GEALC, Buenos Aires (2013)

12. OCDE. La Administración al servicio del público. $3^{a}$ edición. Traducción de 1996. MAP, Madrid (1987).

13. Ramírez-Alujas, A. Gobierno Abierto, Gobierno Digital \& Datos Abiertos de Gobierno (DAG)... ¿Qué? ¿Cómo? ¿Para qué? En CEPAL (2014), http://workspace.unpan.org/sites/Internet/Docume nts/GobiernoAbiertODatos\%20AbiertosCEPAL.p ptx.pdf, acceso por última vez el 20017/01/22.

14. Cruz-Rubio, C. ¿Qué es (y que no es) gobierno abierto? Una discusión conceptual. Eunomía, Revista en Cultura de la Legalidad 8, 37-53 (2015).

15. Naser, A. y Concha, G. El gobierno electrónico en la gestión pública. En Serie 73, ILPES-CEPAL, 142, Santiago de Chile (2011).
16. Jiménez-Gómez, C. Justicia Abierta: transparencia y proximidad de la justicia en el actual contexto de Open Government. En Centro de Estudios Jurídicos y Formación Especializada del Departamento de Justicia. Generalidad de Cataluña. Barcelona (2014).

17. García, M. Justicia electrónica: en busca de la interoperabilidad. En Telléz, E.: Coordinadora. Derecho y TIC. Vertientes actuales, 162-182. UNAM/INFOTEC/CONACYT, Ciudad de México (2016)

18. Sucar, Luis Enrique. Redes Bayesianas, Capítulo 1. Recuperado de http:/ccc.inaoep.mx/ esucar/Clases-

mgp/caprb.pdf, acceso por última vez el 20017/05/10.

19. Terán y Contreras, J. Juicio en línea en la justicia administrativa: Hacia la justicia electrónica en México. Alegatos 80, pp. 2-42 (2012)

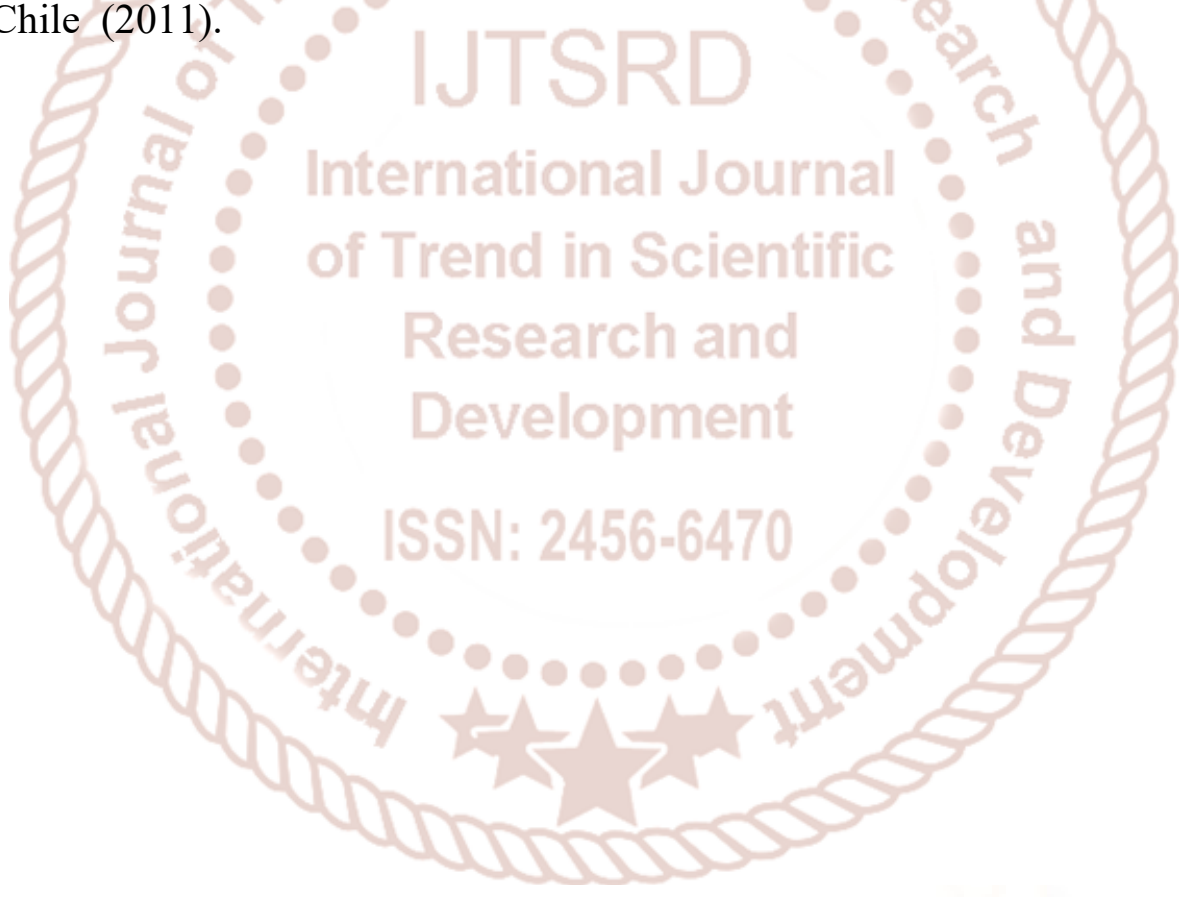

